\title{
CONTRACT FORMATION AND IMPLIED TERMS
}

Wells was struggling to sell some flats. He mentioned this to a neighbour, who put Wells in touch with Devani. Wells and Devani spoke over the telephone. The trial judge found that Devani told Wells that he was an estate agent, and his usual commission was $2 \%+$ VAT. Wells agreed to this, but the parties did not expressly agree upon what was to trigger the commission. Devani subsequently introduced a purchaser to Wells who bought the flats. Was there a binding contract between Wells and Devani? Lewison and McCombe L.JJ. answered "No" (Wells v Devani [2016] EWCA Civ 1106, [2017] Q.B. 959). The trial judge and Arden L.J., dissenting in the Court of Appeal, answered "Yes". The Supreme Court has granted permission to appeal. It is to be hoped that the Justices will clarify the important issues of contract law raised by these simple facts and allow the appeal.

At first instance, Judge Moloney Q.C. found that the contract should not fail on the basis of insufficient agreement or certainty, since a term could be implied that payment would only be required on completion of the transaction. If an officious bystander were to suggest this, "nobody would dispute" such a term (transcript, para. 2.2). However, Lewison L.J. was perhaps concerned (e.g., at [34]) that Devani thought "in his head" that payment would be due earlier - when the purchaser agreed to buy the property - in accordance with his standard terms, which were not sent to Wells until later. Consequently, if an officious bystander asked "Is payment due on completion?", Devani might not have said "Of course!" but rather "No - before then!". Yet it would be unduly harsh to deprive Devani of any contractual right to payment as a result. If the officious bystander asked "Is payment due on completion, unless you both agree to an earlier date of payment?" then both sides would surely have answered "Of course!". Since the judge found that Wells expected to have to pay at some point for Devani's work, such an implied term would not have prejudiced Wells.

Both Lewison and McCombe L.JJ. thought that a term could not be implied to complete the contract because of Scancarriers A/S v Aotearoa International Ltd. [1985] 2 Lloyd's Rep. 419 (PC). That decision is better explained on the basis that the crucial telex sent was "no more than a quotation" and "no contractual relationship was ever intended to be created when the telex was transmitted to the respondents" (at 
422). However, the majority in Wells $v$ Devani relied upon the following dictum of Lord Roskill (ibid.):

the first question must always be whether any legally binding contract has been made, for until that issue is decided a court cannot properly decide what extra terms, if any, must be implied into what is ex hypothesi a legally binding bargain, as being both necessary and reasonable to make that bargain work. It is not correct in principle, in order to determine whether there is a legally binding bargain, to add to those terms which alone the parties have expressed further implied terms upon which they have not expressly agreed and then by adding the express terms and the implied terms together thereby create what would not otherwise be a legally binding bargain.

This dictum is unfortunate. There is no reason to limit the scope of implied terms in this way. It is better to recognise the possibility of implying terms into an agreement that, without such terms, would be insufficiently certain or complete to constitute a binding contract. After all, if an agreement is silent as to even so fundamental a matter as the price, then a term can be implied that a reasonable price should be paid. That it can be implied is very well-established at common law, and has been recognised in the context of contracts with estate agents (see, e.g., Ian Green Residential Ltd. $v$ Asfari [2007] EWHC 1491 (QB), [2007] 3 All E.R. 322, at [96])). Yet implying such a term seems inconsistent with the dictum in Scancarriers.

Certainly, it will not always be appropriate to imply a term to complete a contract or render it sufficiently certain. In May and Butcher $v$ R. [1934] 2 K.B. 17 the parties entered into an arrangement for the sale of tentage which provided that " $[t]$ he price or prices to be paid, and the date or dates on which payment is to be made shall be agreed upon from time to time" (see headnote, at 17). This provision precluded a contract, since the parties had made it clear that there was still more agreeing to be done. But it is significant that the agreement was executory: the tentage had not been delivered. If the tentage had been delivered and the contract executed, then it is more likely that a court would find that the parties did intend to enter into contractual relations. As Steyn L.J. observed in G Percy Trentham Ltd. v Archital Luxfer Ltd. [1993] 1 Lloyd's Rep. 25, at 27, "the fact that the transaction is executed makes it easier to imply a term resolving any uncertainty".

It is to be hoped that the Supreme Court will depart from Lord Roskill's dictum in Scancarriers. Although a decision of the Privy Council, the Court of 
Appeal perhaps felt bound to apply it (see, e.g., at [20]) as a result of its approval by the Court of Appeal in Little v Courage Ltd. (1995) 70 P. \& C.R. 469. But in Little v Courage Millett L.J. only relied upon Scancarriers for the following proposition:

It is in general impossible to imply terms ... into a unilateral contract. This would be to imply a contractual obligation on a person who ex hypothesi is not yet a party to any contract and therefore not yet subject to any contractual obligations on the ground that it is necessary in order to bring a contract into existence. This is wrong in principle...

His reliance might be thought to limit Scancarriers to the context of unilateral contracts. But even that is doubtful: if both parties would have responded "of course!" to a term proposed by an officious bystander, then it is unclear why it should not be implied into a unilateral contract. Moreover, the concerns of Millett L.J. do not obviously point towards the result reached by the Court of Appeal in Wells v Devani, since the implied term to pay the commission upon completion does not impose a further contractual obligation on the "person who ex hypothesi is not yet a party to any contract" (Devani) but only on the person who has made the promise to pay (Wells).

The dissent of Arden L.J. did not focus upon implied terms, but rather upon an interpretation of the oral contract reached. Recourse to interpretation is something of a stretch. As Lewison L.J. rightly pointed out (at [38]), it is difficult to interpret words that were never spoken. Silence is inherently ambiguous. It is because there is silence on an issue that there is scope to imply a term. Following Marks and Spencer plc v BNP Paribas Securities Services Trust Co (Jersey) Ltd. [2016] UKSC 72, [2016] A.C. 742 , the majority was correct to insist that interpretation and implication are distinct (albeit related) exercises. However, the majority's conclusion that terms could only be implied into concluded contracts is not a necessary consequence of the decision in Marks and Spencer, and runs counter to previous authority.

Where work has been carried out by one party on the mutual understanding that it would be paid for by the other, it is suggested (see further Davies [2010] C.L.J. 467) that the preferable approach is for the court to imply terms in order to find a contract, rather than rely upon a claim in unjust enrichment (a possibility which does not appear to have been canvassed in Wells $v$ Devani). In any event, it is unsatisfactory to leave the party who has carried out the work without proper means of redress. In Wells v Devani, the judge found that both parties agreed that Devani 
would be remunerated, yet the Court of Appeal's decision means that Wells does not have to pay Devani anything. This is a surprising result.

It may be that sympathy for Devani is limited because he is an estate agent who failed to comply with his obligations under the Estate Agents Act 1979, notably his obligation to provide Wells with his written terms of business before undertaking any work. But this should have been dealt with under section 18 of the Act, which provides the court with a discretion to find either that Devani is unable to enforce the contract, or that the amount recoverable should be reduced. The judge had held that the amount recoverable by Devani should be reduced by one third, and this was supported by the Court of Appeal. Yet that would only be relevant if there were a binding contract in the first place, which is precisely what the majority's reasoning denied. The significance of whether or not a contract was formed extends well beyond the context of estate agents. The approach of the majority in Wells $v$ Devani inappropriately narrows the scope of contract law.

PAUL S. DAVIES 